\title{
CHAPTER TWENTY
}

\section{DRUG OFFENCES}

\section{Criminalization in International Criminal LaW}

There are ample documents in the system of international criminal law that prohibit illegal trade in narcotic drugs. These documents come under the principles of conventional international criminal law. ${ }^{1}$ Most of these conventions have permitted this trade for medical purposes only and for other purposes which are emphasised in the conventions. It is on this basis that there are indeed a large number of rules and provisions prohibiting, preventing and criminalizing the cultivation, production,

\footnotetext{
${ }^{1}$ Some of these conventions are: 1. International Opium Convention, Hague, 23 January 1912. 8 League of Nations Treaty Series, 187; 6 A.J.I.L. (1912), p. 177; 2. Agreement Concerning the Suppression of the Manufacture of, Internal Trade in, and Use of Prepared Opium, Geneva, 11 February, 1925. 51 L.N.T.S, 337; 3. International Opium Convention, Geneva, 19 February 1925. 81 L.N.T.S, p. 317; 23 A.J.I.L. (1929), p. 135; 4. Protocol to the International Opium Convention, Geneva, 19 February 1925. 81 L.N.T.S. 356; 23 A.J.I.L. (1923), p. 155; 5. Convention for Limiting the Manufacture and Regulating the Distribution of Narcotic Drugs, Geneva, 13 July 1931. 139 L.N.T.S, p. 301; 28 A.J.I.L. (1934), p. 21; 6. Agreement on the Suppression of Opium-Smoking, Bangkok, 27 November 1931. 177 L.N.T.S, p. 373; 7. Convention for the Suppression of the Illicit Traffic in Dangerous Drugs, Geneva, 26 June 1936. 198 L.N.T.S, p. 299; 8. Protocol amending the Agreements, Conventions and Protocols on Narcotic Drugs concluded at the Hague on 23 January 1912, at Geneva on 11 February 1925 and 19 February 1925, and 13 July 1931, in Bangkok on 27 November 1931 and at Geneva on 26 June 1936. 12 U.N.T.S, p. 179; 9. Protocol Bringing under International Control Drugs Outside the Scope of the Convention of 13 July 1931 for Limiting the Manufacture and Regulating the Distribution of Narcotic Drugs, as Amended by the Protocol signed at Lake Success, New York on 11 December 1946, signed in Paris, on 19 November 1948. 44 U.N.T.S, p. 277 ; 10. Protocol for Limiting and Regulating the Cultivation of the Poppy Plant, the Production of, International and Wholesale Trade in, and Use of Opium, New York, 23 June 1953. 456 U.N.T.S. 56; 11. Convention on the Territorial Sea and Contiguous Zone, Geneva, 29 April 1958. 516 U.N.T.S. 205; 12. Single Convention on Narcotic Drugs, New York, 30 March 1961. 520 U.N.T.S. 151; 13. Convention on Psychotropic Substances, Vienna, 21 February 1971. 10 I.L.M. (1971), p. 261; 14. Protocol Amending the Single Convention on Narcotic Drugs, 1961, Geneva, 25 March 1972. 976 U.N.T.S; 11 I.L.M. (1972), p. 804; 15. Convention on the Law of the Sea, Montego Bay, 10 December 1982. 1 I.L.M. (1982), p. 1261; 16. United Nations Convention Against Illicit Traffic in Narcotic Drugs and Psychotropic Substances, 1988. E/CONF. 82/15 and Corr. 1 and 2.
} 
manufacture, possession, exportation, importation, distribution and numerous other acts relating to trade in narcotic drugs without a valid licence. Breaches of these rules and provisions constitute a very serious international crime.

The purpose of all these regulations has not only been to prevent illicit trade in narcotic drugs but also to bring the perpetrators of international crimes under an appropriate jurisdiction for prosecution and punishment. ${ }^{2}$ As a general rule each party to these conventions is bound to adopt

${ }^{2}$ For example Article 26 on Penal Provisions of the Single Convention on Narcotic Drugs 1961, reads that:

1. Subject to its constitutional limitations, each Party shall adopt such measures as will ensure that cultivation, production, manufacture, extraction, preparation, possession, offering, offering for sale, distribution, purchase, sale, delivery on any terms whatsoever, brokerage, dispatch, dispatch in transit, transport, importation and exportation of drugs contrary to the provisions of this Convention, and any other action which in the opinion of such Party may be contrary to the provisions of this Convention, shall be punishable offences when committed intentionally, and that serious offences shall be liable to adequate punishment particularly by imprisonment or other penalties of deprivation of liberty.

2. Subject to the constitutional limitations of a Party, its legal system and domestic law,

(a) (i) Each of the offences enumerated in paragraph 1, if committed in different countries, shall be considered as a distinct offence;

(ii) Intentional participation in, conspiracy to commit and attempts to commit, any of such offences, and preparatory acts and financial operations in connexion with the offences referred to in this article, shall be punishable offences as provided in paragraph 1 ;

(iii) Foreign convictions for such offences shall be taken into account for the purposes of establishing recidivism; and

(iv) Serious offences, heretofore referred to, committed either by nationals or by foreigners shall be prosecuted by the Party in whose territory the offence was committed, or by the Party in whose territory the offender was found if extradition is not acceptable in conformity with the law of the Party to which application is made, and if such offender has not already been prosecuted and judgement given.

(b) It is desirable that the offences referred to in paragraph 1 and paragraph 2 (a) (ii) be included as extradition crimes in any extradition treaty which has been or may hereafter be concluded between any of the Parties, and as between any of the Parties which do not make extradition conditional on the existence of a treaty or on reciprocity, be recognised as extradition crimes; provided that extradition shall be granted in conformity with the law of the Party to which application is made, and that the Party shall have the right to refuse to effect the arrest or grant the extradition in cases where the competent authorities consider that the offence is not sufficiently serious.

3. The provisions of this article shall be subject to the provisions of the criminal law of the Party concerned on questions of jurisdiction. 
certain rules and obligations which may be necessary under its domestic system to criminalize the given conduct and especially to provide serious penalties for the production, manufacture, extraction, preparation, offering, offering for sale, distribution, sale, delivery in whatever way, brokerage, dispatch, dispatch in transit, transport, importation or exportation of any narcotic drugs and any other psychotropic substances. ${ }^{3}$

4. Nothing contained in this article shall affect the principle that the offences to which it refers shall be defined, prosecuted and punished in conformity with the domestic law of a Party.

${ }^{3}$ For example Article 22 on Penal Provisions of the Convention on Psychotropic Substances, 1971, reads that:

1. (a) Subject to its constitutional limitations, each Party shall treat as a punishable offence, when committed intentionally, any action contrary to a law or regulation adopted in pursuance of its obligations under this Convention, and shall ensure that serious offences shall be liable to adequate punishment, particularly by imprisonment or other penalty of deprivation of liberty.

(b) Notwithstanding the preceding sub-paragraph, when abusers of psychotropic substances have committed such offences, the Parties may provide, either as an alternative to conviction or punishment or in addition to punishment, that such abusers undergo measures of treatment, eduction, after-care, rehabilitation and social reintegration in conformity with paragraph 1 of article 20.

2. Subject to the constitutional limitations of a Party, its legal system and domestic law,

(a) (i) if a series of related actions constituting offences under paragraph 1 has been committed in different countries, each of them shall be treated as a distinct offence,

(ii) intentional participation in, conspiracy to commit and attempts to commit, any of such offences, and preparatory acts and financial operations in connexion with the offences refer to in this article, shall be punishable offences as provided in paragraph 1 ;

(iii) foreign convictions for such offences shall be taken into account for the purpose of establishing recidivism; and

(iv) serious offences heretofore referred to committed either by nationals or by foreigners shall be prosecuted by the Party in whose territory the offence was committed, or by the Party in whose territory the offender is found if extradition is not acceptable in conformity with the law of the Party to which application is made, and if such offender has not already been prosecuted and judgement given.

(b) It is desirable that the offences referred to in paragraph 1 and paragraph 2 (a) (ii) be included as extradition crimes in any extradition treaty which has been or may hereafter to concluded between any of the Parties, and, as between any of the Parties which do not make extradition conditional on the existence of a treaty or on reciprocity, be recognised as extradition crimes; provided that extradition shall be granted in conformity with the law of the Party to which application is made, and that the Party shall 


\section{Prohibitions in Islamic International Criminal LaW}

Islamic international criminal law does not provide, as does the system of international criminal law, provisions governing the prohibition of narcotic offences, but basically prohibits the use of narcotic drugs according to common Islamic purposes. The fact is that "drugs have the same effect on the human mind as alcohol, and they therefore produce the same public harm that led to the prohibition of the former." ${ }^{4}$ The prohibition of narcotic drugs in Islamic law is based on the theory that social interests must be protected by the law and therefore any action which contradicts social development or creates civil or domestic problems between individuals, groups and the state is juridically wrong and must be punished according to the law. Furthermore, the prohibition of narcotic drugs within Islamic law also rests on the theory that since narcotic drugs are harmful to the human body and may handicap physical growth and ability, any involvement in it must be recognised as criminal. Islamic law has in one sense the function of a medical treatment of the body and for this reason it may even prohibit other substances in narcotic drugs which may be discovered in the future, on the condition that such substances are harmful to the human body. Permission for the use of narcotic drugs may be given under particular circumstances which are vital for the treatment of certain illnesses.

Narcotic offences under Islamic criminal law are penalized under the term hudud meaning fixed penalties. On a wider plane it means 'prevention, hindrance, restraint, prohibition, and hence a restrictive ordinance or statute of Allah, respecting things lawful and unlawful. ${ }^{5}$ In addition to this, hudud offences are against the fundamental principles of

have the right to refuse to effect the arrest or grant the extradition in cases where the competent authorities consider that the offence is not sufficiently serious.

3. Any psychotropic substance or other substance, as well as any equipment used in or intended for the commission of any of the offences referred to in paragraphs 1 and 2 shall be liable to seizure and confiscation.

4. The provisions of this article shall be subject to the provisions of the domestic law of the Party concerned on questions of jurisdiction.

5. Nothing contained in this article shall affect the principle that the offences to which it refers shall be defined, prosecuted and punished in conformity with the domestic law of a Party.

${ }^{4}$ Don Peretz, Richard U. Moench and Safia K. Mohsen, Islam: Legacy of the Past, Challenge of the Future (1984), p. 109.

${ }^{5}$ Muhammad Iqbal Siddiqi, The Penal Law of Islam (1979), p. 50. Quoted in Matthew 
Islamic law and are considered acts against divine law and are therefore prosecutable and punishable by the state jurisdiction under which the given criminal conduct is committed.

According to Islamic criminal law it is the intentional involvement in narcotic offences such as the selling or possession of narcotic drugs which causes the application of criminal provisions and not unintentional elements. ${ }^{6}$ Thus, although Islamic criminal law has criminalized the possessions of narcotic drugs, it is against its equal standard of justice to punish those who have not intentionally engaged in the commission of such criminal conduct. In this way, the Islamic criminal system attempts to safeguard the interests of the accused over whom Islamic criminal jurisdiction is exercised. ${ }^{7}$

The prohibition of narcotic drugs in Islamic law has not only a national characterization, but also, an international characterization. This is because, according to the theory of Islamic law, acts by individuals or their state within their own territories should not harm other nations in the international community as a whole. This is on the grounds that all men must be treated equally before the law of God. Analogies in narcotic offences under Islamic international criminal law may therefore be made to similar prohibitions stated in the system of conventional international criminal law. These include aspects such as production, manufacture, extraction, preparation, offering for sale, distribution, sale, delivery in whatever way, dispatch, transport, importation and exportation of any narcotic drugs. This inclusion is with the reservation that the system of international criminal law has regulated certain provisions for all these activities in conventional international criminal law, while the same conclusions in Islamic international criminal law are deduced from its purposes, functions and sources which forbid, prohibit and make any intentional involvement in narcotic drugs a prosecutable and punishable

Lippman, Sean McConville, and Mordechai Yerushalmi, Islamic Criminal Law and Procedure: An Introduction (1988), p. 38.

${ }^{6}$ However, one cannot disagree with the fact that the Islamic Republic of Iran has, strongly, violated the system of international criminal justice and Islamic criminal law concerning the prosecution and punishment of those who are engaged in narcotic offences. It has, mostly, applied capital punishment violating the most fundamental principles of universal human rights and Islamic human rights law.

${ }^{7}$ It is useful to note here that Islamic criminal law does not punish those who are addicted to drugs while they attempt to stop their addiction. There will be inflicted hudud penalties, if after they have been cured of their dependency they become addicted again. Lippman, McConville and Yerushalmi, Islamic Criminal Law and Procedure, p. 48. This philosophy of punishment should be modified to the modern theory of treatment. 
crime. Clear examples of this practice can be examined in the legislations of many states in which Islamic law has been an influence, such as the legislation and practice of Iran. ${ }^{8}$ An involvement with any type of illegal narcotic drugs can be specified under the principle of taboo.

The procedure for jurisdiction and punishment may differ in Islamic law from other legal systems. This does not preclude the comparative analysis of both systems of international criminal law. As an acceptable general principle of the system of international criminal law, so long as there are not yet regulations permitting the permanent International Criminal Court (ICC) to exercise jurisdiction over the perpetrators of all international crimes for the purpose of effective prosecution of criminals, the implementation and enforcement of the system remains the privilege of various selected legal systems.

${ }^{8}$ In fact, many of those who are engaged in narcotic drug trade in Iran have been punished by the application of capital punishment. This method of punishment has been internationally objected by a number of international institutions but without any effective result. The United Nations has also condemned the practice and encouraged the internal authorities for the abolition of capital punishment and the implementation of the principles of international human rights law. 